Thorax, 1980, 35, 101-106

\title{
Diagnostic and therapeutic implications of ectopic hormone production in small cell carcinoma of the lung
}

\author{
MOGENS HANSEN, MOGENS HAMMER, AND LOTTE HUMMER
}

\begin{abstract}
From the Department of Chemotherapy $R I I-R$ V, Finsen Institute, and Department of Internal Medicine C, Bispebjerg Hospital, and the Departments of Nephrology P and Nuclear Medicine, Rigshospitalet, Copenhagen, Denmark
\end{abstract}

ABSTRACT In 75 unselected and untreated patients with small cell carcinoma of the lung, plasma ACTH, serum calcitonin, and antidiuretic hormone $(\mathrm{ADH})$ in plasma and urine were related to corresponding clinical symptoms and biochemical findings at the time of diagnosis. The significance of elevated concentrations of these substances in relation to treatment was also investigated. Plasma ACTH concentrations were increased in 22 patients (29\%), and 25 patients $(33 \%)$ were considered to have inappropriate ADH secretion. Only one patient had definite hypokalaemic alkalosis, and one patient pronounced hyponatraemia, with associated clinical syndromes of ectopic ACTH and ADH secretion. Serum calcitonin concentrations were increased in 48 patients $(65 \%)$. No related clinical symptoms were disclosed, and all these patients had normal serum calcium concentrations. Thirty-three of 66 patients $(50 \%)$ had raised levels of free cortisol in a 24-hour urine and these levels were significantly related to plasma ACTH concentrations. The median survival was slightly shorter in patients with increased values of the three substances, but this was not related to increased plasma ACTH concentrations and was not statistically significant. Survival rates and results of treatment were independent of the pretreatment levels of the three substances.

Ectopic production of $\mathrm{ACTH}$ and $\mathrm{ADH}$ in malignant tumours is well documented, and usually occurs in relation to small cell carcinoma of the lung (scc). ${ }^{1-3}$ Recently the production of calcitonin in scc has also been documented. ${ }^{4-6}$ While no clinical signs related to hypercalcitonaemia have been observed, clinical syndromes have been related to the ectopic production of ACTH and ADH. ${ }^{2} 8$

In a review of 138 cases with scc Kato et $a l^{9}$ found Cushing's syndrome in $2.8 \%$ of the patients. Investigating 41 treated and untreated patients with scc Gilby et $a l^{10}$ found increased concentrations of plasma cortisol before and after dexamethasone suppression in half of the patients, but only three were considered to have the ACTH syndrome. The inappropriate $\mathrm{ADH}$ syndrome (SIADH) is claimed to occur in up to $20 \%$ of

Address for reprint requests: Dr Mogens Hansen, Department of Chemotherapy RII, Finsen Institute, 49 Strandboulevarden, DK-2100 Copenhagen, Denmark. patients with scc, ${ }^{11}$ and Gilby et al, ${ }^{10}$ using water loading, found an overall prevalence in about $40 \%$ of their sample. Both ACTH ${ }^{12-14}$ and $\mathrm{ADH}^{15}$ appear to be produced in almost all cases of scc.

We have studied ectopic ACTH, ADH, and calcitonin production at the time of diagnosis in 75 unselected patients with scc. The relationships between these three substances, their clinical features, and the implications for response to treatment and survival have been investigated.

\section{Methods}

The study included 75 unselected patients with $\mathrm{scc}^{16}$ referred to Medical Department C, Bispebjerg Hospital, between May 1975 and March 1976 (46 patients), and to the Finsen Institute between May 1976 and February 1977 (29 patients). Fifty-three patients $(71 \%$ ) were men and $22(29 \%)$ were women with a median age of 64 years (range $38-75$ years). Sixty-two patients 
below the age of 70 years were treated in randomised trials. ${ }^{17} 18$

Before starting chemotherapy or radiotherapy or both two 24-hour urine samples were collected, the second being acidified with $10 \mathrm{ml} 0.1 \mathrm{HCl}$. Between these two collections a fasting blood sample was collected. Blood was taken on ice and centrifuged at $4^{\circ} \mathrm{C}$ immediately, and plasma and serum were kept below $-20^{\circ} \mathrm{C}$ until analysis.

Plasma ACTH $^{19}$ and serum calcitonin ${ }^{20}$ were measured by radioimmunoassay techniques. Two samples for analysis of plasma ACTH were obtained with a 10-minute interval, and the lower value was used (in healthy control subjects $76 \mathrm{ng}$ / $1=$ mean +2 SD).

Arginine-vasopressin (ADH) was measured by radioimmunoassay in acidified urine ${ }^{21}$ and in plasma. ${ }^{22}$ Analyses on urine were attempted in the first 46 patients, but a sample was not obtained in five patients. If frozen plasma was available, analysis were performed in patients with raised urine ADH or decreased plasma osmolality or both, thereby including 31 patients, 15 of whom had also urine ADH measured.

In the first 24-hour urine sample free cortisol, ${ }^{23}$ ketogenic steroids (KGS), ${ }^{24}$ creatinine, and osmolality were measured. Routine plasma analyses were performed for osmolality, sodium, chloride, potassium, standard bicarbonate, calcium, and phosphorus.

\section{Results}

ACTH

None of the patients had the physical signs of Cushing's syndrome and only one was clinically suspected of ectopic ACTH production because of oedema, polyuria, and thirst. This patient also had hypokalaemic alkalosis (K :2.2 $\mathrm{mmol} / \mathrm{l}$, $\left.\mathrm{HCO}_{3}{ }^{-}: 34 \cdot 2 \mathrm{mmol} / \mathrm{l}\right)$ and a plasma ACTH of $199 \mathrm{ng} / \mathrm{l}$. Five other patients had hypokalaemia, the lowest value being $2.8 \mathrm{mmol} / 1$. Serum bicarbonate in these five patients ranged from 24.4 to $29.5 \mathrm{mmol} / 1$. Plasma ACTH concentrations were above $76 \mathrm{ng} / 1$ in 22 patients $(29 \%-95 \%$ confidence limits: $19-41 \%$ ). The highest value, 199 $\mathrm{ng} / \mathrm{l}$, was obtained in the above-mentioned patient, while the remaining results had values below $157 \mathrm{ng} / 1$. The median value of ACTH in all patients was $64 \mathrm{ng} / 1$, twice the median value in healthy control subjects. ${ }^{19}$ Thirty-three of 66 patients $(50 \%)$ had increased urinary excretion of free cortisol, including 18 of 47 patients (36\%) with plasma ACTH below $76 \mathrm{ng} / \mathrm{l}$, and 15 of 19 patients $(79 \%)$ with plasma ACTH above $76 \mathrm{ng} / \mathrm{l}$.
The median value of urinary cortisol was 7260 nmol/24 hours (range: 468-13500) in the 18을 patients with plasma ACTH below $76 \mathrm{ng} / \mathrm{l}$, and $750 \mathrm{nmol} / 1$ (range: $455-10020$ ) in the 15 patients with plasma ACTH above $76 \mathrm{ng} / \mathrm{l}$. Only nines patients $(14 \%)$ had significantly increased ketogenic steroids, and eight of these also had in-:creased free cortisol. The patient with increased $\vec{\omega}$ ketogenic steroids and normal free cortisol had an increased plasma ACTH, while eight patients with raised plasma ACTH and free cortisol hadic normal ketogenic steroid levels.

\section{ANTIDIURETIC HORMONE}

Only one patient was clinically suspected of음 SIADH because of lethargy, weakness, and ${ }^{-}$ oliguria. This patient had hyponatraemia $\left(\mathrm{Na}^{+}: \mathbb{0}\right.$ $123 \mathrm{mmol} / \mathrm{l})$, hypotonic plasma with higher urine osmolality (plasma: 244 and urine $345 \mathrm{mosmol} / \mathrm{kg}$ $\mathrm{H}_{2} \mathrm{O}$ ), and inappropriately increased concentrations of urine $\mathrm{ADH}(34 \mathrm{mU} / \mathrm{l})$ and plasma $\mathrm{ADH}_{\infty}^{\circ}$ $(3 \cdot 1 \mathrm{pg} / \mathrm{ml})$. Eleven more patients had plasma sodium between 132 and $135 \mathrm{mmol} / \mathrm{l}$. Altogether, 32 patients $(43 \%)$ had hypotonic plasma (osmolality below $280 \mathrm{mosmol} / \mathrm{kg} \mathrm{H}_{2} \mathrm{O}$ ). In only two of these patients was the osmolality of urine belowo that of plasma. Urine ADH was measured in $15 \frac{1}{\Omega}$

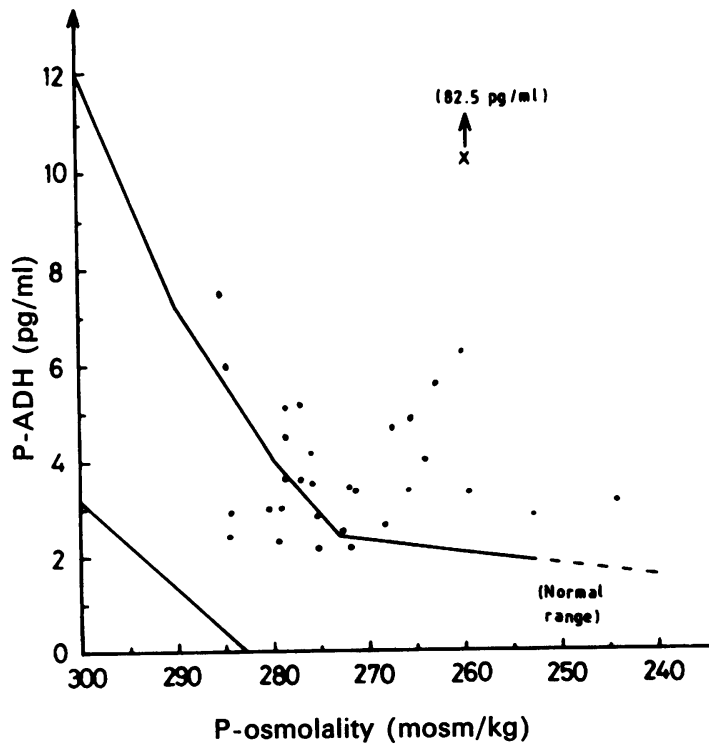

Figure Corresponding values of plasma ADH and plasma osmolality in 31 patients with small cell carcinoma of the lung. The range of similar values in healthy control subjects falls between the two solid lines. 
of these patients and was increased in 13, from 6 to $6250 \mathrm{mU} / 1$.

The relation between plasma ADH and plasma osmolality in 31 patients is shown in the figure. Twenty-two of 31 patients $(71 \%)$ had inappropriately increased ADH concentrations, including two with normal plasma osmolality. Taking both ADH and osmolality in plasma and urine into account, 25 patients $(33 \%-95 \%$ confidence limits: $23-45 \%$ ) had inappropriate ADH secretion.

\section{CALCITONIN}

Serum calcitonin concentrations were measured in 74 patients and were increased in $48(65 \%-$ 95\% confidence limits: $53-76 \%$ ), while serum calcium concentrations were normal in all patients. These data have been presented in detail elsewhere. $^{25}$

\section{RELATIONSHIPS}

The relationships between increased plasma ACTH and serum calcitonin and inappropriate $\mathrm{ADH}$ secretion are seen in table 1 . The estimated frequency calculated from the occurrence of ele-

Table 1 Relationship between increased plasma $A C T H$, serum calcitonin $(C T)$ and inappropriate $A D H$ secretion $(A D H)$

\begin{tabular}{lll}
\hline Increased substance & Frequency & \\
\cline { 2 - 3 } & Estimated & $\begin{array}{l}\text { Found }(95 \% \\
\text { confidence limits) }\end{array}$ \\
\hline ACTH+ADH & & $0.08(0.03-0.17)$ \\
ACTH+CT & 0.10 & $0.20(0 \cdot 12-0.31)$ \\
ADH+CT & 0.18 & $0.21(0.13-0.32)$ \\
ACTH+ADH+CT & 0.21 & $0.07(0.02-0.15)$ \\
\hline
\end{tabular}

*Calculated from the frequency of individual increases: ACTH 0.29; ADH 0.33; calcitonin (CT) 0.65 .

Table 2 Response to treatment in 61 patients with small cell carcinoma of the lung in relation to levels of plasma $A C T H$, serum calcitonin $(C T)$, and inappropriate $A D H$ secretion (SIADH)

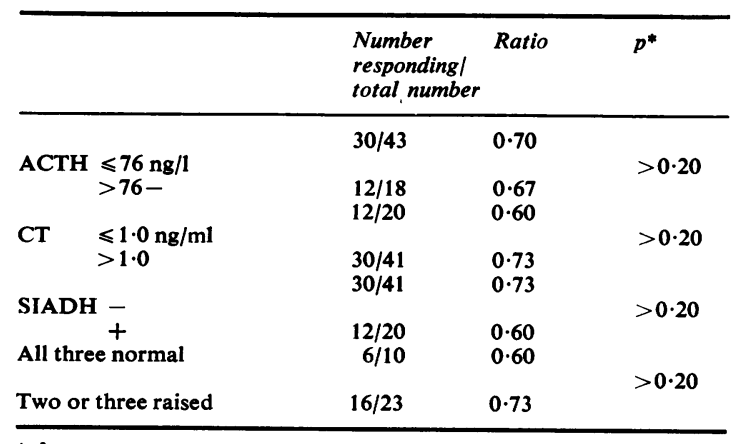

$x^{2}$ test. vations of the individual substance is also shown in table 1. It appears that the frequency of concomitant elevations found was the same as the estimated one. Altogether, 63 patients $(84 \%)$ had either increased plasma ACTH or serum calcitonin concentrations or inappropriately increased ADH values.

\section{RESPONSE TO TREATMENT}

Sixty-one patients with measurable or evaluable disease were treated. Forty-two patients $(69 \%)$ responded with a decrease by more than $50 \%$ of the product of the longest perpendicular diameters of measurable lesions or by more than $75 \%$ of evaluable lesions. Minor or no changes or progressive disease were found in 19 patients (non-responding). The relation of responding and non-responding patients to the levels of plasma ACTH and serum calcitonin and the occurrence of inappropriate ADH secretion is given in table 2 . No statistically significant differences were found for the response rate in patients with one of the substances raised and in patients with normal levels. Nor was any statistically significant difference observed between patients with normal levels of all three substances and patients with two or three concomitantly increased substances.

\section{SURVIVAL}

Sixty-two patients were treated in prospective clinical trials. ${ }^{17} 18$ Survival data for these patients with regard to the level of the three substances are given in table 3 . The median survival was somewhat longer for patients with normal levels of each of the three hormones and for patients with no increased levels, compared to patients with increases of the respective substance and patients with two or three increased substances, but none of these differences was statistically significant. Considering the long-term results, the proportions of patients surviving more than one year, and the number of patients still alive without treatment and free of disease are almost identical (table 3). There is a slight increase in long-term survival in patients without inappropriate ADH secretion as well as for patients with none of the three substances raised, but these differences are not statistically significant.

\section{Discussion}

The finding of Cushing's syndrome in a middleaged man might very well be the result of small cell carcinoma, thereby indicating a diagnostic value, ${ }^{326}$ though the present results show that the 
Table 3 Survival results for 62 patients with small cell carcinoma treated in randomised trials in relation to levels of plasma ACTH, serum calcitonin (CT), and inappropriate ADH secretion (SIADH)

\begin{tabular}{|c|c|c|c|c|c|c|c|}
\hline & & $\begin{array}{l}\text { Median } \\
\text { survival } \\
\text { (days) }\end{array}$ & $\begin{array}{l}\text { Range } \\
\text { (days) }\end{array}$ & $p^{*}$ & $\begin{array}{l}\text { Number alive } \\
>365 \text { days }\end{array}$ & $\begin{array}{l}\text { Number alive } \\
\text { and free of } \\
\text { disease } \$\end{array}$ & $\begin{array}{l}\text { Ratio } \\
(\%)\end{array}$ \\
\hline \multirow{2}{*}{ ACTH } & $\leqslant 76 \mathrm{ng} / 1$ & 325 & $1-1210+$ & \multirow{2}{*}{$>0.05$} & $17 / 44(39 \%)$ & 3 & 7 \\
\hline & $>76 \mathrm{ng} / 1$ & 298 & $5-1057+$ & & $8 / 18(44 \%)$ & 2 & 11 \\
\hline \multirow{2}{*}{$\mathrm{CT}$} & $\leqslant 1.0 \mathrm{ng} / \mathrm{ml}$ & 357 & $8-1187+$ & \multirow{2}{*}{$>0.05$} & $9 / 21(43 \%)$ & 2 & 10 \\
\hline & $>1.0 \mathrm{ng} / \mathrm{ml}$ & 262 & $1-1210+$ & & $15 / 40(38 \%)$ & 3 & 8 \\
\hline \multirow{2}{*}{ SIADH } & - & 360 & $5-1210+$ & \multirow{2}{*}{$>0.05$} & $18 / 41(44 \%) \dagger$ & 4 & 10 \\
\hline & + & 260 & $1-874+$ & & $6 / 21(29 \%) \dagger$ & 1 & 5 \\
\hline \multicolumn{2}{|c|}{ All three normal } & 363 & $161-1187+$ & \multirow{2}{*}{$>0.05$} & $6 / 11(55 \%) \ddagger$ & 1 & 9 \\
\hline \multicolumn{2}{|c|}{ Two or three raised } & 262 & $1-1057+$ & & $9 / 24(38 \%) !$ & 2 & 8 \\
\hline
\end{tabular}

clinical syndrome is uncommon in such patients. Clinical symptoms and hypokalaemic alkalosis were extremely rare, and moderately increased values of urinary cortisol and plasma ACTH are not specific for patients admitted with scc. Increased levels of plasma and urinary corticoid levels have been demonstrated previously in patients with lung cancer. ${ }^{1027} 28$ Lichter and Siret ${ }^{28}$ found that the increased levels occurred particularly in patients within six months of death. These results are not in disagreement with the demonstration of ACTH in tumour tissue, as the secretion of ACTH from tumour suppresses pituitary production of ACTH. ${ }^{2930}$ To cause increased plasma ACTH concentrations the secretion from a tumour must, therefore, exceed the normal pituitary secretion. In this regard it should be noted that the median value of plasma ACTH in our patients is twice the median value in healthy control subjects, thus suggesting subclinical ectopic production of ACTH. This may also explain some of the increased urinary cortisol values in patients with plasma ACTH concentrations below $76 \mathrm{ng} / \mathrm{ml}$. It is also noteworthy that increased plasma ACTH concentrations are within the usual range for the pituitary Cushing syndrome, ${ }^{2}$ which may account for the rare occurrence of hypokalaemic alkalosis in the present patients. Although Bagshawe ${ }^{31}$ and Ross ${ }^{26}$ suggested that hypokalaemic alkalosis was particularly related to the ectopic ACTH syndrome, Prunty et $a l^{32}$ found that potassium depletion was related to the degree of adrenal hyperfunction independently of the source of ACTH.
The inappropriate ADH syndrome was also extremely rare. In only one patient was plasmao sodium decreased to a degree that caused clinical symptoms. When ADH was related to plasma osmolality, inappropriate ADH secretion was, $\stackrel{\circ}{\mathbb{Q}}$ however, found in one-third of the patients. Inappropriately increased plasma ADH concentra-oํㅡㄹ tions in asymptomatic patients were also found by Padfield et al. $^{33}$

In this investigation $\mathrm{ACTH}, \mathrm{ADH}$, and calcitonin levels were increased in a significant number of patients with untreated and newlyo diagnosed scc. According to the estimated and actual frequencies of concomitant increases, each of the three hormonal polypeptides appeared to be raised independently of the others. This suggests that the property of ectopic hormone production $\mathrm{O}_{\mathrm{O}}$ is not confined to a particular group of scc. However, preliminary results produced by Coombeso et $a l^{34}$ indicate that tumour content of ACTH and calcitonin may be related. The mechanisms that cause ectopic production as well as secretion of the products are not known. The present resultsN indicate that production and secretion occur con- $-\mathrm{O}$ comitantly in one tumour in more than half the cases. The concept of multiple production is? further supported by the findings of multiples peptide and amine products in plasma and tumour from some patients with the ectopic ACTH syn-0 drome. ${ }^{4133536}$ Investigations on the occurrenced of these three polypeptides in the same tumours related to the histological subtypes and electronmicroscopical studies would be of interest.

Median and long-term survival was almost the 
same for patients with and without increased plasma ACTH concentrations. Similarly, Yalow et $a l^{37}$ did not observe any relation between median survival and the pre-treatment plasma level of immunoreactive "big" ACTH in patients with metastatic disease. Median survival was shorter and long-term results appeared to be inferior for patients with inappropriate ADH secretion compared to patients without. Although no statistical significance was obtained for the ADH related data, these results are contrary to previous general statements claiming that the ectopic ACTH syndrome shortened life, while the SIADH had no influence. ${ }^{23} 29$ Possibly, the ectopic ACTH syndrome may complicate the condition in untreated patients, while all clinical symptoms, hyperglycaemia, and electrolyte disturbances disappear in patients responding to chemotherapy (Hansen, unpublished observations). Accordingly, if tumour response is obtained by the treatment, survival might be suggested to be independent of the initial ectopic hormonal levels. This suggestion is supported by the response rates and long-term results in this investigation.

We are indebted to Jens Dencker Christensen, MSc, and Peter Bie, MD, who performed the analyses of urinary ADH and osmolality, respectively. The work was supported by grants from King Christian X Foundation and the Danish Cancer Society.

\section{References}

1 Amatruda TT, Mulrow PJ, Callagher JC, Sawyer WH. Carcinoma of the lung with inappropriate antidiuresis. Demonstration of antidiuretichormone-like activity in tumor extract. $N$ Engl $J$ Med 1963; 269:544-9.

2 Rees LH, Ratcliffe JG. Ectopic hormone production by non-endocrine tumours. Clin Endocrinol 1974; 3:263-99.

3 Said SI. Endocrine role of the lung in disease. Am J Med 1974; 57:453-65.

4 Abe K, Adachi I, Miyakawa S et al. Production of calcitonin, adrenocorticotropic hormone, and $\beta$-melanocyte-stimulating hormone in tumors derived from amine precursor uptake and decarboxylation cells. Cancer Res 1977; 37:4190-4.

5 Baylin SB, Weisburger WR, Eggleston JC et al. Variable content of histaminase, L-dopa decarboxylase and calcitonin in small-cell carcinoma of the lung. $N$ Engl J Med 1978; 299:105-10.

6 Silva OL, Becker KL, Primack A, Doppman J, Snider RH. Ectopic secretion of calcitonin by oat-cell carcinoma. $N$ Engl J Med 1974; 290: 1122-4.
7 Bartter FC, Schwartz WB. The syndrome of inappropriate secretion of antidiuretic hormone. Am J Med 1967; 42: 790-806.

8 Meador CF, Liddle GW, Island DP et al. Cause of Cushing's syndrome in patients with tumors arising from "non-endocrine" tissue. J Clin Endocrinol Metab 1962; 22:693-703.

9 Kato Y, Ferguson TB, Bennett DE, Burford TH. Oat cell carcinoma of the lung. A review of 138 cases. Cancer 1969; 23:517-24.

10 Gilby ED, Rees LH, Bondy PK. Ectopic hormones as markers of response to therapy in cancer. Amsterdam: Excerpta Medica, 1975.

11 Vorherr H. Para-endocrine tumor activity with emphasis on ectopic ADH secretion. Oncology 1974; 29:382-416.

12 Bloomfield GA, Holdaway JM, Corrin B et al. Lung tumours and ACTH production. Clin Endocrinol 1977; 6:95-104.

13 Horai $T$, Nishihara $H$, Tateishi $R$, Matsuda $M$, Hattori S. Oat-cell carcinoma of the lung simultaneously producing ACTH and serotonin. J Clin Endocrinol Metab 1973; 37:212-9.

14 O’Neal LW, Kipnis, DM, Luse SA, Lacy PE, Jarett $L$. Secretion of various endocrine substances by ACTH-secreting tumours-gastrin, melanotropin, norepinephrine, serotonin, parathormone, vasopressin, glucagon. Cancer 1968; 21:1219-32.

15 Morton JJ, Kelly P, Padfield PL. Antidiuretic hormone in bronchogenic carcinoma. Clin Endocrinol 1978; 9:357-70.

16 Kreyberg L. Histological typing of lung tumours. Geneva: World Health Organisation, 1967.

17 Hansen HH, Dombernowsky P, Hansen M, Hirsch F. Chemotherapy of advanced small-cell anaplastic carcinoma. Ann Intern Med 1978; 89:17781.

18 Hansen M, Hansen HH, Dombernowsky P. Restaging of long-term survivors with small cell anaplastic carcinoma of the lung. Proc Am Soc Clin Oncol 1979; 20:511.

19 Hummer L. A radioimmunoassay of plasma corticotropin. In: Radioimmunoassay and related procedures in medicine 1977, vol 2. Vienna: International Atomic Energy Agency, 1978:391403.

20 Almqvist S, Telenius-Berg M, Wästhed B. Serum calcitonin in medullary thyroid carcinoma. Radioimmunoassay technique and diagnostic value. Acta Med Scand 1974; 196:177-80.

21 Christensen JD, Jensen SE. A comparative study on bioassay and radioimmunoassay of vasopressin in human urine. Acta Endocrinol 1978; 87:283-91.

22 Hammer M. Radioimmunoassay of 8-argininevasopressin (antidiuretic hormone) in human plasma. Scand J Clin Lab Invest 1978; 38:707-16.

23 Kehlet $H$, Binder C, Nielsen MD. Urinary free corticosteroids determined by competitive proteinbinding technique in Cushing's syndrome. Ugeskr Laeger 1972; 134:2438-41. 
24 Wilson H, Lipsett MB. Use of periodase oxidation in the clinical analysis of urine corticoids. Anal Biochem 1963; 5:217-25.

25 Hansen M, Rehfeld JF, Stadil F. Small cell carcinoma of the lung: relation of calcitonin to bone marrow metastases, parathormone and gastrin. Acta Med Scand 1979; 206:215-8.

26 Ross EJ. Endocrine and metabolic manifestations of cancer. Br Med J 1972; 1:735-8.

27 Hatch HB, Segaloff A, Ochsner A. Adrenocortical function in bronchogenic carcinoma: study of 100 patients. Ann Surg 1965; 161:645-8.

28 Lichter I, Sirett NE. Serial measurement of plasma cortisol in lung cancer. Thorax 1975; 30: 91-4.

29 Bower BF, Gordan GS. Hormonal effects of non-endocrine tumors. Ann Rev Med 1965; 16: 83-118.

30 Liddle GW, Island DP, Ney RL, Nicholson WE, Shimizu N. Nonpituitary neoplasms and Cushing's syndrome. Arch Intern Med 1963; 111: 471-5.

31 Bagshawe KD. Hypokalaemia, carcinoma and
Cushing's syndrome. Lancet 1960; 2:284-7.

32 Prunty FTG, Brooks RV, Dupré J et al. Adreno-O cortical hyperfunction and potassium metabolism $\frac{\bar{\rho}}{5}$ in patients with "non-endocrine" tumors and $\widehat{\varnothing}$ Cushing's syndrome. J Clin Endocrinol Metab $1963 ; 23: 737-46$.

33 Padfield PL, Morton JJ, Brown et al. Plasma $\vec{\circ}$ arginine vasopressin in the syndrome of antidiuretic hormone excess associated with broncho- $\vec{\omega}$ genic carcinoma. Am J Med 1976; 61:825-31.

34 Coombes RC, Ellison ML, Neville AM. Bio- $\vec{x}$ chemical markers in bronchogenic carcinoma. Br J Dis Chest 1978; 72:263-87.

35 Liddle GC, Givens JR, Nicholson WE, Island ${ }^{*}$ DP. The ectopic ACTH syndrome. Cancer Res 1965; 25:1057-61.

36 Rees LH, Bloomfield GA, Rees GM, Corrin B, 울 Franks LM, Ratcliffe JG. Multiple hormones in a

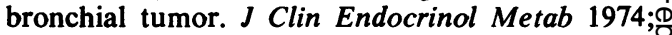
38: $1090-7$.

37 Yalow RS, Wolf J, Lee LE. Ectopic ACTH in bronchogenic carcinoma. Proc Am Soc Clin Oncol 1977; 18:277. 